\title{
Germination of Anatolian Black Pine (Pinus nigra subsp.pallasiana) Seeds from the Lakes Region of Turkey: Geographic Variation and Effect of Storage
}

\author{
Fatih TEMEL', Süleyman GÜLCÜ², Zafer ÖLMEZ1', Asskın GÖKTÜRK \\ ${ }^{1}$ Artvin Çoruh University, Faculty of Forestry, 08000 Artvin, Turkey; ftemel@artvin.edu.tr \\ ${ }^{2}$ Süleyman Demirel University, Faculty of Forestry, 32260 Isparta, Turkey
}

\begin{abstract}
Effects of 10-year storage on germination of seeds in 191 Anatolian Black Pine trees from 23 populations in the Lakes Region of Turkey were investigated. Germination tests were conducted with both fresh (in year 1999) and stored (in year 2009) seeds and variation in germination was related to geographic features of the populations. Significant reductions in germination rate (from $79.93 \%$ to $30.68 \%$ ) and germination percentage (from $95.99 \%$ to $58.41 \%$ ) were observed after 10 -year storage. Germination characteristics seem to be associated with humidity of population locations. Seeds from more inland (i.e., continental) populations germinated slower but attained higher germination percentage for both seed sets. Germination percentage of stored seeds is highest at elevations with high humidity. Greater attention should be given to environmental conditions of seed sources in storing Anatolian Black Pine seeds in the Lakes Region of Turkey as it is a very important tool in ensuring continuous seedling production and genetic conservation.
\end{abstract}

Keywords: geographic variation, long term seed storage, Pinus nigra subsp. pallasiana, seed germination

\section{Introduction}

Anatolian Black Pine (Pinus nigra subsp. pallasiana) is the second most widely distributed forest tree species after P. brutia in Turkey. The species covers, as either pure or mixed stands, about 4.2 million ha of 21.2 million ha total forest land in Turkey. Climatically, it grows transitional region extending between maritime climate and continental climate and it penetrates as near as the inner Anatolian steppe (Atalay and Efe, 2010). Being naturally found in climatically diverse environments is related to the species' high genetic diversity (Kaya and Temerit, 1993, 1994; Tolun et al., 2000) and ecological tolerance (Atalay and Efe, 2010). Anatolian Black Pine has been identified as one of the target species for Turkish National Tree Breeding Programme (Koski and Antola, 1993).

Due to its low environmental requirements, it is being used heavily in re- and afforestation efforts in Turkey, especially in the central Anatolia. Until year 2009, 488000 ha of land has been planted with Anatolian Black Pine (Atalay and Efe, 2010). In addition, nearly half of Anatolian Black Pine forests (1.8 million ha) are degraded and need to be rehabilitated via reforestation (Anonymous, 2006). Since continuous seedling production is essential for this species, as over 100 million Anatolian Black Pine seedlings are produced every year ( $25 \%$ of Turkey's total seedling production; http://www.agm.gov.tr/AGM/files/ istatistikler2009/3.10.xls), storage of the seeds harvested during seed years is important.
Long term storage of seed is often essential not only for continuous seedling production but also for gene conservation via seed banking (Chin, 1994; Gómez-Campo, 1985; Hawkes, 1990) in coniferous forest tree species as abundant seed production does not happen every year. In general, most pine seeds are orthodox and can be safely dried to 6-7\% moisture content. At these moisture contents and at a storage temperature of 3 to $5^{\circ} \mathrm{C}$ most orthodox tree seeds will exhibit little deterioration over 5-15 years of storage (Gosling, 2007). In addition, Bonner (2008) implied that orthodox seeds can be dried to moisture contents of $10 \%$ or less, and in this condition they can be successfully stored at subfreezing temperatures (e.g., Pita et al., 1998). Total germination of Pinus nigra seeds from Muğla, Turkey decreased from $99 \%$ to $91 \%$ along with significant reduction in germination rate after 10-year storage at $4-7^{\circ} \mathrm{C}$ (Atay et al., 1970; Ürgenç, 1973). Pinus ponderosa seeds stored at $0^{\circ} \mathrm{C}$ for 7 years did not show a loss of viability (Allen, 1957). Similar responses to storage were observed in $P$. elliotii, $P$. patula, $P$. radiata and $P$. taeda after 6 years of storage at $-16^{\circ} \mathrm{C}$ (Donald and Jacobs, 1990). Storage of seeds for extended periods, however, seems to affect seed vigor and viability. Germination of P. echinata seeds reduced by $32 \%$ after 10 years of storage at $1.1^{\circ} \mathrm{C}$ and $6 \%$ moisture content (Barnett, 1969). Germination of 10-year stored Pinus sylvestris seeds reduced significantly for both cold and frozen storage conditions (Hilli et al., 2003). In addition to reduction in germination capability, 15-year storage caused abnormal germina- 
268

tion in P. elliotii, P. patula, P. radiata and P. taeda (Donald and Jacobs, 1990). After 50 years of storage germination rate of $P$. echinata and $P$. elliotii were reduced to 25 and $66 \%$, respectively, probably due to chromosomal aberrations (Barnett and Vozzo, 1985).

While there are many studies on germination of pine seeds, not much attention is given to geographic variation in seed germination. Provenance level variation in germination was observed in Pinus halepensis (Falusi et al., 1983), P. pinaster (Falleri, 1994), P. brutia (Boydak et al., 2003), P. sylvestris (Tilki, 2005), and P. nigra (Mataruga et al., 2010). In all of these studies provenance response to moisture content of the germination test (i.e., drought stress during the test) was significantly different among provenances; provenances from humid regions suffering most in the presence of drought stress.

While there are two studies on germination of stored Anatolian Black Pine seeds from one provenance (Atay et al., 1970; Ürgenç, 1973), geographic variation in germination of stored Anatolian Black Pine seeds has not received much attention. Thus, goals of this study were 1 ) to determine how long-term storage affects germination capability of the pine seeds, and 2) to relate variation in seed germination before and after the storage to geographic features of the seed sources. Germination of Anatolian Black Pine seeds obtained from 23 natural populations in the Lakes
Region of Turkey was investigated immediately after seed collection in 1999 and after 10 years of storage in 2009.

\section{Materials and methods}

Open pollinated seeds were collected from 191 Anatolian Black Pine trees at 23 natural populations ( 4 to 13 trees in each population) in the Lakes Region of Turkey (Gülcü and Üçler, 2008). The sampled populations' elevations ranged from 1210 to $1540 \mathrm{~m}$ and they are scattered between $36^{\circ} 52^{\prime}-38^{\circ} 06^{\prime} \mathrm{N}$ and $23^{\circ} 22^{\prime}-31^{\circ} 20^{\prime} \mathrm{E}$ ( Tab. 1). Sampled trees were selected randomly with following restrictions: 1 ) they are to be separated by at least 150 $\mathrm{m}$ to minimize the rate of self pollination, 2) elevation range of families must be no greater than $300 \mathrm{~m}$ within any one population, and 3) they are to be approximately of the same age ( \pm 10 years), ranging from 70 to 80 years. Healthy cones from the last year's crop were collected from the middle part of the crowns. Cone collection and seed extraction were performed between December 1998 and February 1999. Cones were brought to laboratory, placed in mesh sacks and placed in a well aerated warm room to induce opening of cone scales. Seeds were extracted from the cones and stored in sealed plastic bags at $4 \pm 1^{\circ} \mathrm{C}$ until use.

Tab. 1. Geographic information on sampled Pinus nigra subsp. pallasiana populations in the Lakes Region of Turkey

\begin{tabular}{|c|c|c|c|c|c|c|c|}
\hline $\begin{array}{l}\text { Pop. } \\
\text { No. }\end{array}$ & Forest District-Locality & $\begin{array}{c}\text { No. of } \\
\text { trees }\end{array}$ & Elevation $(\mathrm{m})$ & Aspect $^{1}$ & $\begin{array}{c}\text { Latitude } \\
(\mathrm{N})\end{array}$ & $\begin{array}{c}\text { Longitude } \\
\text { (E) }\end{array}$ & $\mathrm{DM}^{2}$ \\
\hline 1 & Tota-Tota & 8 & 1540 & $\mathrm{~N}$ & $37^{\circ} 33^{\prime} 52^{\prime \prime}$ & $31^{\circ} 07^{\prime} 49^{\prime \prime}$ & 79 \\
\hline 2 & Sütçüler-Sanlı & 6 & 1330 & $\mathrm{NE}$ & $37^{\circ} 25^{\prime} 54^{\prime \prime}$ & $31^{\circ} 03^{\prime} 11^{\prime \prime}$ & 63.5 \\
\hline 3 & Sipahiler-Sipahiler & 5 & 1280 & SW & $37^{\circ} 40^{\prime} 57^{\prime \prime}$ & $30^{\circ} 57^{\prime} 29^{\prime \prime}$ & 91.3 \\
\hline 4 & Ş.Karaağaç-Örenköy & 5 & 1320 & $\mathrm{E}$ & $38^{\circ} 06^{\prime} 30^{\prime \prime}$ & $31^{\circ} 13^{\prime} 19^{\prime \prime}$ & 140 \\
\hline 5 & Y. Bademli-Bademli & 8 & 1340 & E & $37^{\circ} 42^{\prime} 15^{\prime \prime}$ & $31^{\circ} 20^{\prime} 40^{\prime \prime}$ & 98.1 \\
\hline 6 & Pazarköy-Aktaş & 7 & 1400 & NW & $37^{\circ} 45^{\prime} 2^{\prime \prime}$ & $31^{\circ} 04^{\prime} 54^{\prime \prime}$ & 100 \\
\hline 7 & Pazarköy-Köydüzü & 8 & 1510 & SE & $37^{\circ} 41^{\prime} 28^{\prime \prime}$ & $31^{\circ} 02^{\prime} 39^{\prime \prime}$ & 92.2 \\
\hline 8 & Aksu-K.Belentepe & 9 & 1430 & $\mathrm{E}$ & $37^{\circ} 43^{\prime} 17^{\prime \prime}$ & $31^{\circ} 14^{\prime} 16^{\prime \prime}$ & 97.7 \\
\hline 9 & Kuzukulağı-Eldere & 4 & 1440 & $\mathrm{~N}$ & $37^{\circ} 39^{\prime} 17^{\prime \prime}$ & $31^{\circ} 12^{\prime} 14^{\prime \prime}$ & 90 \\
\hline 10 & Eğirdir-Çamyol & 9 & 1230 & SE & $37^{\circ} 47^{\prime} 17^{\prime \prime}$ & $30^{\circ} 57^{\prime} 19^{\prime \prime}$ & 103 \\
\hline 11 & Eğirdir-Yuvalı & 10 & 1420 & W & $37^{\circ} 43^{\prime} 27^{\prime \prime}$ & $30^{\circ} 57^{\prime} 09^{\prime \prime}$ & 95.5 \\
\hline 12 & Eğirdir-Kurucaova & 9 & 1210 & $\mathrm{~N}$ & $37^{\circ} 41^{\prime} 37^{\prime \prime}$ & $30^{\circ} 54^{\prime} 29^{\prime \prime}$ & 91.4 \\
\hline 13 & Y.Gökdere-Y.Gökdere & 12 & 1270 & W & $37^{\circ} 40^{\prime} 09^{\prime \prime}$ & $30^{\circ} 50^{\prime} 39^{\prime \prime}$ & 87.6 \\
\hline 14 & A.Gökdere-İnalanı & 12 & 1360 & $\mathrm{NE}$ & $37^{\circ} 38^{\prime} 14^{\prime \prime}$ & $30^{\circ} 50^{\prime} 15^{\prime \prime}$ & 83.4 \\
\hline 15 & Burdur-Kayabaşı & 6 & 1430 & $\mathrm{~N}$ & $37^{\circ} 33^{\prime} 42^{\prime \prime}$ & $30^{\circ} 13^{\prime} 54^{\prime \prime}$ & 84.7 \\
\hline 16 & Çamoluk-Yeşildağ & 11 & 1450 & NW & $37^{\circ} 30^{\prime} 12^{\prime \prime}$ & $30^{\circ} 15^{\prime} 14^{\prime \prime}$ & 78.3 \\
\hline 17 & Çamoluk-Erikli & 8 & 1360 & W & $37^{\circ} 27^{\prime} 21^{\prime \prime}$ & $30^{\circ} 12^{\prime} 12^{\prime \prime}$ & 75.6 \\
\hline 18 & Kemer-Delmeoluk & 5 & 1280 & $\mathrm{~N}$ & $37^{\circ} 21^{\prime} 41^{\prime \prime}$ & $30^{\circ} 09^{\prime} 04^{\prime \prime}$ & 70.2 \\
\hline 19 & Gölhisar-Ercekbaşı & 8 & 1450 & NW & $37^{\circ} 02^{\prime} 09^{\prime \prime}$ & $23^{\circ} 29^{\prime} 10^{\prime \prime}$ & 52.9 \\
\hline 20 & Gölova-Ecelderesi & 11 & 1400 & NW & $37^{\circ} 18^{\prime} 37^{\prime \prime}$ & $23^{\circ} 38^{\prime} 46^{\prime \prime}$ & 85.6 \\
\hline 21 & Tefenni-Gökarık & 7 & 1530 & SW & $37^{\circ} 15^{\prime} 45^{\prime \prime}$ & $23^{\circ} 42^{\prime} 11^{\prime \prime}$ & 85.5 \\
\hline 22 & Dirmil-Masta & 13 & 1480 & $\mathrm{NE}$ & $36^{\circ} 52^{\prime} 13^{\prime \prime}$ & $23^{\circ} 25^{\prime} 05^{\prime \prime}$ & 35.9 \\
\hline 23 & İbecik-Elmalıyurt & 10 & 1500 & $\mathrm{~N}$ & $36^{\circ} 53^{\prime} 21^{\prime \prime}$ & $23^{\circ} 22^{\prime} 07^{\prime \prime}$ & 36.1 \\
\hline
\end{tabular}

${ }^{1} \mathrm{~N}=$ North, E=East, $\mathrm{S}=$ South, W=West $;{ }^{2}$ Distance to the Mediterranean Sea in kilometers 


\section{Germination tests}

A total of hundred healthy seeds from each tree were soaked in aerated tap water for $24 \mathrm{~h}$ before germination tests were conducted. The seeds were placed on moistened filter papers in Petri dishes. Petri dishes were placed in a germination chamber under dark conditions at $22 \pm 1^{\circ} \mathrm{C}$ and number of germinated seeds was recorded at seventh and $21^{\text {st }}$ day of incubation. The germination tests were conducted soon after seed extraction in 1999 and after 10 years of storage at $4 \pm 1^{\circ} \mathrm{C}$ in 2009 . Germination rate (GR) and germination percentage (GP) for each of 1999 and 2009 tests were calculated (Tab. 2). Germination of Pinus nigra seeds is usually rapid and $50 \%$ germination is achieved before $7^{\text {th }}$ day of germination tests (e.g., Pita et al., 1998). Thus, in our study proportion of seeds germinated until the $7^{\text {th }}$ day of germination test is used as GR. Five additional variables were created from GR and GP in 1999 and 2009. GP_DIFF and GR_DIFF are differences between 1999 and 2009 tests in GP and GR, respectively. GPGR1999 and GPGR2009 are proportion (of 100 seeds tested) of seeds germinated after the $7^{\text {th }}$ day of the tests in 1999 and 2009, and GPGR9909 indicates difference between 1999 and 2009 in GPGR (Tab. 2).

Tab. 2. Description of germination and location variables employed in the study

\begin{tabular}{|c|c|}
\hline Variable & Definition \\
\hline \multicolumn{2}{|c|}{ Germination variables } \\
\hline GP1999 & Percent germination in year 1999 \\
\hline GR1999 & Germination rate in year 1999 \\
\hline GP2009 & Percent germination in year 2009 \\
\hline GR2009 & Germination rate in year 2009 \\
\hline GP_DIFF & $=\mathrm{GP} 1999-\mathrm{GP} 2009$ \\
\hline GR_DIFF* & $=$ GR1999 - GR2009 \\
\hline GPGR1999" & $=\mathrm{GP} 1999-\mathrm{GR} 1999$ \\
\hline GPGR2009" & = GP2009 - GR2009 \\
\hline GPGR9909 & $=$ GPGR1999 - GPGR2009 \\
\hline \multicolumn{2}{|c|}{ Geographic variables } \\
\hline Latitude & Latitude (in UTM) \\
\hline Longitude & Longitude (in UTM) \\
\hline Elevation & Elevation above sea level (m) \\
\hline Aspect & N, NE, E, SE, SW, W, NW \\
\hline DM & Distance to the Mediterranean Sea $(\mathrm{km})$. \\
\hline
\end{tabular}

* As proportion of all seeds tested

\section{Statistical analyses}

One-way analysis of variance (ANOVA) was conducted to test differences among populations or among trees within populations with respect to germination variables. GP1999 was arcsinus transformed to meet normal distribution assumption of ANOVA. All reported values for this variable are in original scale unless otherwise noted. The t-test was employed to investigate difference in GR and GP before and after the seed storage (i.e., for GPGR1999, GPGR2009 and GPGR9909). Correlation and regression analyses were employed to investigate relationship between geographic variables at each location and seed germination (Tab. 2). SAS statistical package was used for all analyses (SAS Institute Inc., 1990).

\section{Results and discussion}

\section{Objective 1: Effect of storage on seed germination}

Except for GR1999, all variables were significantly different among populations. Both GR and GP were at least twice as much in year 1999 than in 2009 and these differences were statistically significant among populations. Both GP and GR decreased significantly after 10year storage. On average, GP decreased from $95.99 \%$ to $58.41 \%$ and GR from $79.93 \%$ to $30.68 \%$. The reductions in GP and GR are significantly different among populations (Tab. 3).

Populations were also significantly different with respect to proportion of germinated seeds between seventh and $21^{\text {st }}$ day of the germination test both in 1999 (GPGR1999) and 2009 (GPGR2009). This difference was more pronounced in year 2009 than in $1999(27.74 \%$ vs. $16.06 \%$, respectively) as indicated by significant t-test result for GPGR9909 (Tab. 3).

Tab. 3. Overall means, location mean ranges and standard deviations for the variables included in the study (see Tab. 2 for variable definitions)

\begin{tabular}{|c|c|c|c|c|}
\hline \multirow{2}{*}{ Variable } & \multirow{2}{*}{$\begin{array}{l}\text { Overall } \\
\text { Mean }\end{array}$} & \multicolumn{2}{|c|}{ Location Mean } & \multirow{2}{*}{$\begin{array}{l}\text { Standard } \\
\text { deviation }\end{array}$} \\
\hline & & Min. & Max. & \\
\hline \multicolumn{5}{|c|}{ Germination variables } \\
\hline GP1999a & $95.99^{\circ}$ & 90.80 & 98.86 & 4.89 \\
\hline GR1999 & $79.93^{\text {ns }}$ & 46.80 & 90.86 & 20.88 \\
\hline GP2009 & $58.41^{\cdots}$ & 26.94 & 79.58 & 21.02 \\
\hline GR2009 & $30.68^{* * *}$ & 9.44 & 51.67 & 18.53 \\
\hline GP_DIFF & $37.57^{\cdots}$ & 17.25 & 67.61 & 20.78 \\
\hline GR_DIFF & $49.25^{\cdots *}$ & 17.80 & 73.36 & 25.58 \\
\hline GPGR1999 & 16.06 & 4.50 & 51.60 & 20.89 \\
\hline GPGR2009 & $27.74^{* *}$ & 8.25 & 50.63 & 16.92 \\
\hline GPGR9909 & $-11.68^{* *}$ & -33.25 & 5.10 & 22.10 \\
\hline \multicolumn{5}{|c|}{ Geographic variables } \\
\hline Elevation & 1392.72 & 1210 & 1540 & 93.76 \\
\hline DM & 81.17 & 35.9 & 140 & 21.86 \\
\hline
\end{tabular}

${ }^{\text {ns }}$ Non-significant; ${ }^{*}$ P-value $<0.05$ for $\mathrm{H} 0$ : location means are equal as a result of ANOVA; ${ }^{* * *} \mathrm{P}$-value $<0.001$ for $\mathrm{H} 0$ : location means are equal as a result of ANOVA; ${ }^{* * *}$ P-value < 0.001 for H0: mean of paired differences between 1999 and $2009=0$ for the variables written in bold as a result of $\mathrm{t}$-test; ${ }^{\mathrm{a}}$ Arcsinus transformed to meet the assumptions of ANOVA. The values are in original scale

\section{Objective 2: Geographic variation in seed germination}

Trends in GR with respect to location variables were similar in both test years; seeds coming from western part of the studied populations at higher elevations near the Mediterranean Sea germinated faster, although the effect of elevation is not significant for 2009 test (Tab. 4). 
270

Tab. 4. Pearson correlations between population mean of each seed germination variable and geographic variables. See Tab. 2 for variable definitions

\begin{tabular}{ccccc}
\hline & Latitude & Longitude & Elevation & DM \\
\hline GP1999 & $0.48^{\circ}$ & $0.57^{\circ}$ & -0.11 & $0.51^{\circ}$ \\
GR1999 & -0.36 & $-0.52^{\circ}$ & $0.44^{\circ}$ & $-0.60^{\circ}$ \\
GP2009 & -0.12 & 0.12 & -0.03 & 0.19 \\
\hline GR2009 & $-0.61^{\circ}$ & $-0.45^{\circ}$ & 0.22 & -0.36 \\
GP_DIFF & 0.21 & -0.03 & 0.01 & -0.11 \\
\hline GR_DIFF & 0.27 & 0.03 & 0.12 & -0.09 \\
GPGR1999 & $0.43^{\circ}$ & $0.60^{\circ}$ & -0.43 & 0.66 \\
\hline GPGR2009 & 0.46 & $0.59^{\circ}$ & -0.24 & 0.58 \\
GPGR9909 & -0.10 & -0.08 & -0.14 & -0.02 \\
\hline
\end{tabular}

${ }^{*} \mathrm{P}$-value $<0.05$

Contrary to GR, more inland and eastern locations had greater GP in year 1999. In year 2009, however, there was no significant relationship between geographic variables and GP (Tab. 4). Proportion of germinated seeds between the seventh and $21^{\text {st }}$ days of the germination test (GPGR) showed similar patterns in both test years; it increases as the populations move eastward and inland at lower elevations (Tab. 4). There is no significant relationship between geographic variables and differences in germination rate (GR_DIFF), total germination (GP_DIFF) and proportion of germinated seeds after the seventh day of the tests (GPGR9909) between the two test years (Tab. 4).

Significant differences were observed among aspects of seed sources for GP2009, GR2009, GP_DIFF, GR_DIFF and GPGR2009. Highest GR and GP were observed in seeds coming from populations facing west. In general, high GR is associated with high GP except for seeds from east aspect, where seeds were slow to germinate but attained second highest total germination (Fig. 1a). Reduction in GR and GP was highest in seeds coming from populations facing southeast (Fig. 1b). The slowest germination was observed in seeds coming from populations facing east and southeast as over $60 \%$ of all germination occurred after the $7^{\text {th }}$ day of the test (Fig. 1c).

Fresh pine seeds, in general, are easy to germinate and provide uniform germination (Gosling, 2007; Krugman and Jenkinson, 2008). Findings of current study are in ac-
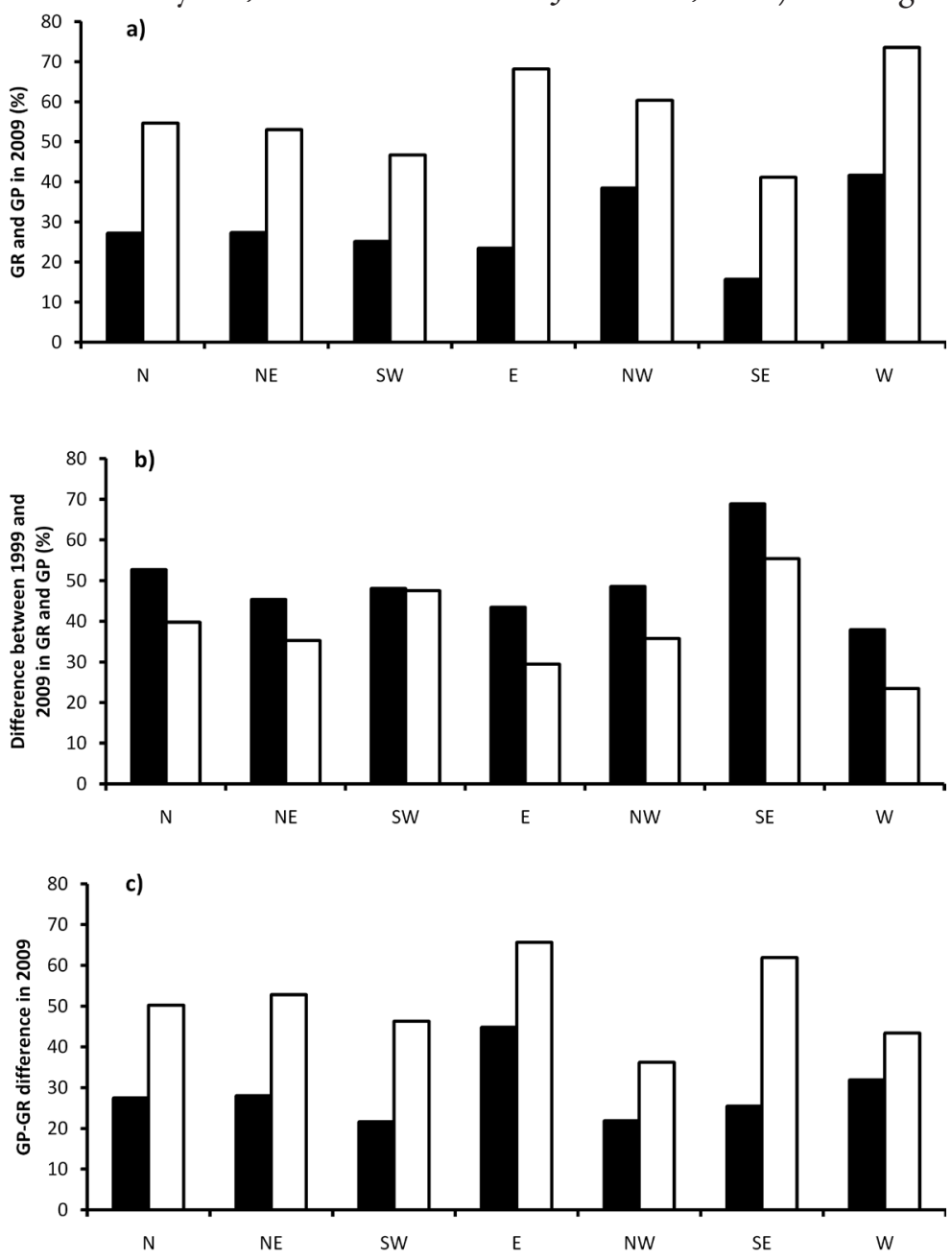

Fig. 1. Germination rate (\%, black bars) and germination percentage (\%, white bars) in 2009 test (a), difference between 1999 and 2009 tests for GR (\%, black bars) and GP (\%, white bars) (b), and difference between GP and GR in 2009 test as proportion of all tested seeds (black bars) and of total germinated seeds (white bars) (c) for each aspect of populations 
cordance with the earlier studies. In the germination test conducted immediately after seed collection (the 1999 test) almost all of the seeds from 23 populations germinated (population mean range: $90.80-98.86 \%$ ). Thus, populations under investigation differed significantly, albeit slightly, for GP in this test. Greater variation was observed for GR than that of GP in this test (population mean range: 46.80 - 90.86\%), but within population variation was so high that no statistically significant differences were observed among populations (Tab. 3).

Pinus nigra seeds are orthodox, meaning that they can be stored safely for long periods at $3-5^{\circ} \mathrm{C}$ once their moisture content is reduced to 6-8\% (Gosling, 2007). While Pinus ponderosa (Allen, 1957), P. elliotii, P. patula, $P$. radiata and $P$. taeda (Donald and Jacobs, 1990) seeds maintained their germination capabilities after six- to seven-year storage, Barnett (1969) reported 32\% reduction in germination of $P$. echinata seeds stored for 10 years. In our study, both GR and GP decreased significantly after the storage. Effect of storage was more pronounced in
GR than in GP. In the 2009 test, mean GR decreased by about $62 \%$ (to $30.68 \%$ ) and mean GP by about $39 \%$ (to $58.41 \%$ ). On population mean basis, GP was as low as 26.94\% (Tab. 3). Ürgenç (1973) reached to a similar result with 10-year stored Anatolian Black Pine seeds where GR suffered more from long term storage than GP.

Effect of seed source location attributes on GR and GP were found to be similar in both fresh (1999 test) and stored (2009 test) seeds (Tab. 4). As the seed source moves inland, hence distances from the Mediterranean Sea, germination speed (GR) decreases (Fig. 2) but total germination (GP) increases (Fig. 3). Elevation of the seed sources, on the other hand, has a reverse effect on germination speed; it increases as seed source moves to higher elevations (Fig. 4). Germination percentage of fresh seeds seems to be not affected by seed source elevation in 1999 test, but total germination increases until 1400-1450 m above sea level then decreases in 2009 test (Fig. 5).

The study area is located in transition zone between maritime and continental climates and thus represents hu-

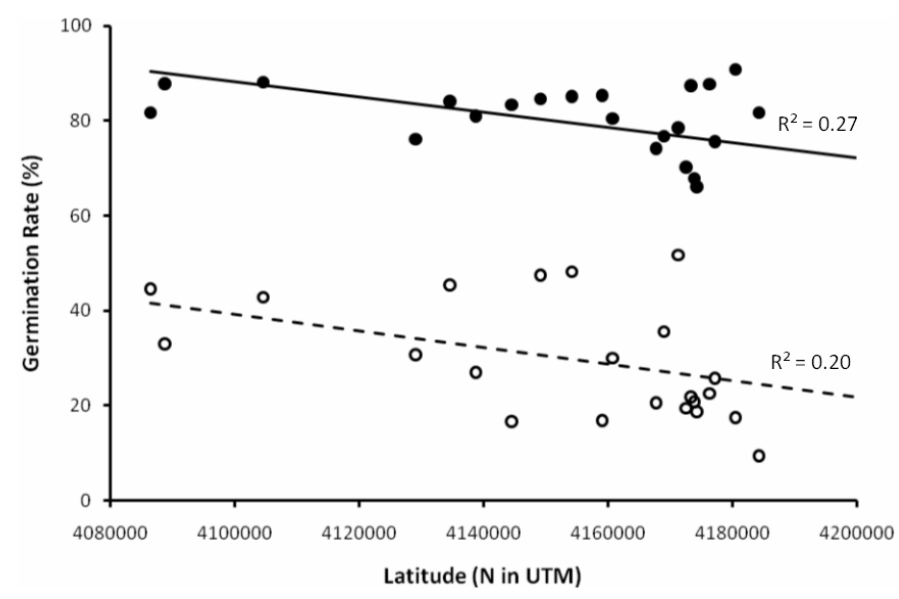

Fig. 2. Relationship between germination rate of Anatolian Black Pine seeds and latitude of the seed sources in $1999(\bullet)$ and in 2009 (०) tests

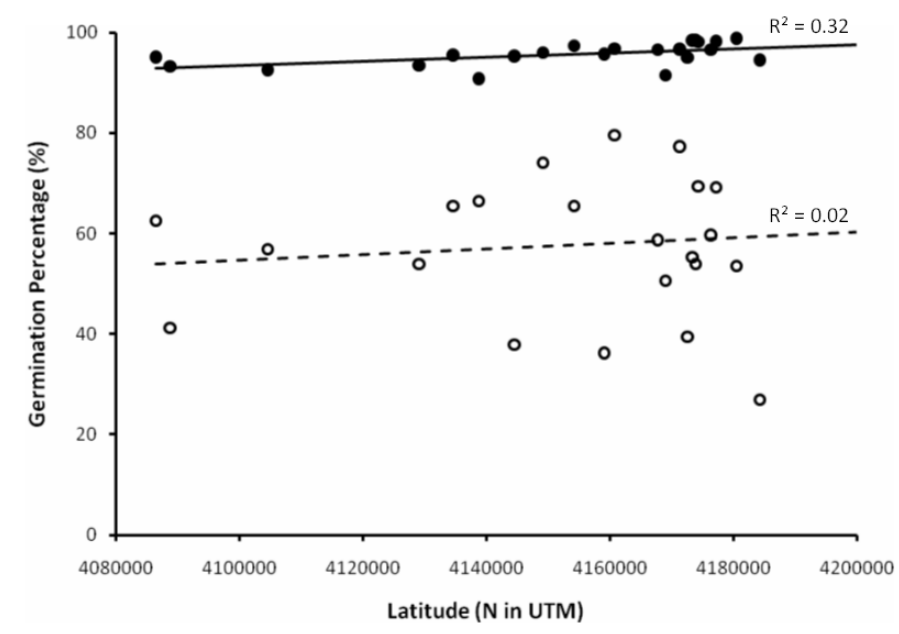

Fig. 3. Relationship between germination percentage of Anatolian Black Pine seeds and latitude of the seed sources in $1999(\bullet)$ and in 2009 (०) tests 


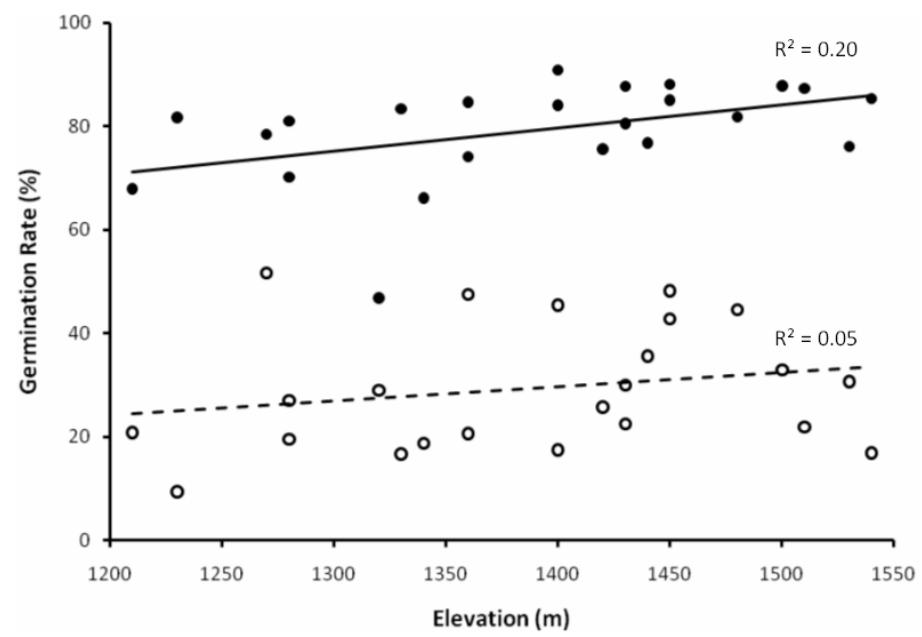

Fig. 4. Relationship between germination rate of Anatolian Black Pine seeds and elevation of the seed sources in $1999(\bullet)$ and in 2009 (०) tests

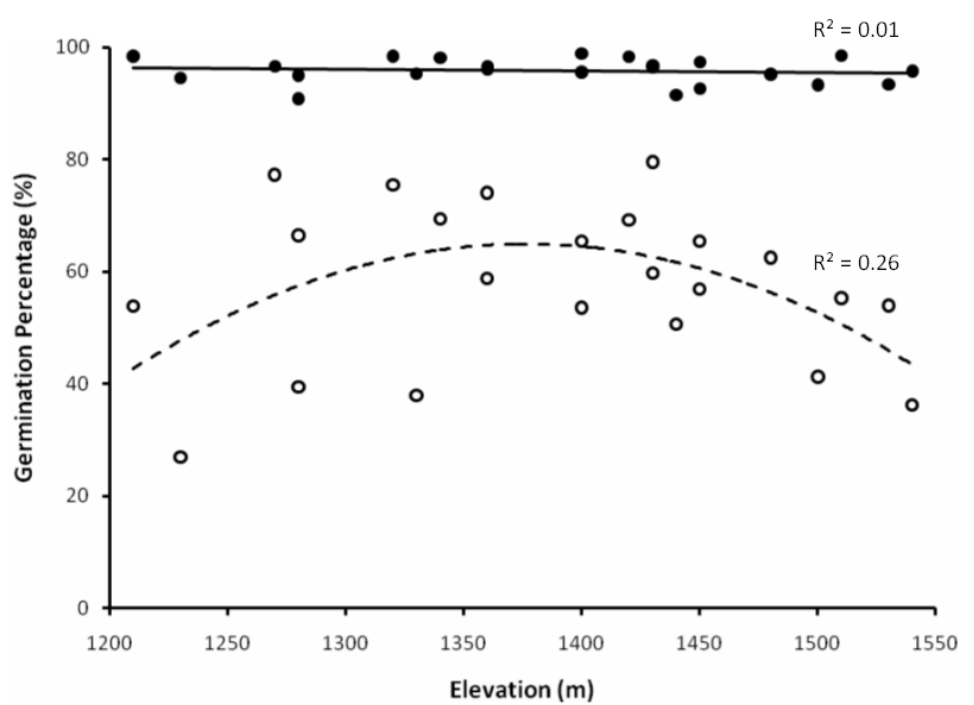

Fig. 5. Relationship between germination percentage of Anatolian Black Pine seeds and elevation of the seed sources in $1999(\bullet)$ and in 2009 (०) tests

mid, sub-humid and semiarid climate conditions (Atalay and Efe, 2010). Variation in germination speed with geography may be an evolutionary response to these climatic conditions. Seed germination characteristics are known to be controlled, at least partially, by genes (El-Kassaby et al., 1992; Whittington, 1973); therefore, local populations of a widely distributed species may develop adaptive variability in germination ecology (Quinn, 1977). Seeds in drier climates (i.e., more inland sources) evolved to increase chances of seedling survival by delaying germination until suitable moisture conditions are present for seedling establishment. Increase in total germination with increased continentality may be a corollary of this adaptation. Similarly, humidity and rainfall increases due to orographic rains on the mountains in the region with elevation, providing suitable environment for rapid germination. Total germination pattern of stored seeds with elevation is in accordance with the nature of orographic rainfalls; they increase until certain altitude and then decrease resulting in drier conditions at higher elevations. Weber and Sorensen (1992) reported a gradient in germination speed of Pinus ponderosa seeds with rainfall patterns in seed sources in central Oregon. In addition, provenance differences in seed germination have been explained by the conditions of the site of origin for several species (Boydak et al., 2003; Fraser, 1971; Gibson and Bachealard, 1987; Moore and Kidd, 1982; Wang et al., 2010). Mechanism for this adaptation may be via differences in water uptake characteristics of seeds. In a recent paper on Pinus nigra seeds from five provenances in the Balkans, Mataruga et al. (2010) have reported that Pinus nigra seeds coming from some of the harsher environments within each provenance took up lower amount of water than those coming from more suitable environments.

Improper storage conditions and biochemical and physiological changes in seeds have been shown to reduce 
germination capacity of conifer seeds. Among the storage conditions storage temperature and moisture content of the seeds are shown to be most influential. For most pine species storage at $4^{\circ} \mathrm{C}$ with $6-8 \%$ moisture content is recommended (Gosling, 2007). In our study, air dried seeds were stored at $4^{\circ} \mathrm{C}$ in sealed plastic bags, but their initial moisture contents were not measured. Thus, the effect of seed moisture content on reductions in germination rate and percentage cannot be excluded. Biochemical and physiological changes during the storage include oxidative damage (Tommasi et al., 2006), alterations in reserve substances (Simola, 1974), chromosomal dislocations (Roberts, 1972; Simak and Gustafsson, 1968), and leakage of substances from seed (Roberts, 1972). Seasonal periodicity has also been shown to affect germination of pine seeds, especially in seeds stored for longer periods (Barnett and Mamonov, 1989). To what extent reductions in germination occurred as a result of which of these factors in this study are beyond the scope of this paper and requires further attention.

One shortcoming of this study is that due to lack of enough number of seeds germination tests were conducted with only one replication. Our sample, on the other hand, includes seeds from 3-12 trees from the sampled populations. Therefore, although there was only one replication in each germination test, each population was represented by at least three different trees in the germination tests.

\section{Conclusions}

Long-term storage of Anatolian Black Pine seeds is essential not only for continuous seedling production, but also for genetic conservation in Turkey. Both germination rate and germination percentage of Anatolian Black Pine seeds decrease after 10-year storage and these reductions are found to be associated with environmental conditions of seed sources in the Lakes Region. It should be noted, however, moisture content of stored seeds has direct influence on their viability and in this study initial moisture contents of the stored seeds from different origins are not known. Thus, to what extent variation in initial moisture content of the seeds, if any, influenced germination patterns of stored Anatolian Black Pine seed sources requires further investigation.

\section{Acknowledgements}

Authors wish to thank Dr. Mehmet Özalp for helpful comments during manuscript preparation.

\section{References}

Allen GS (1957). Storage of behaviour of conifer seeds in sealed containers held at $0,32^{\circ} \mathrm{F}$ and room temperature. J For 55:278-281.

Anonymous (2006). Orman Varlı̆̆ımız. T.C. Çevre ve Orman Bakanlığı, Orman Genel Müdürlügü, Ankara. (in Turkish)
Atalay I, Efe R (2010). Ecology of The Anatolian Black Pine (Pinus nigra Arnold subsp. pallasiana (Lamb.) Holmboe) and its Dividing into Regions in Terms of Seed Transfer. Forest Tree Seeds and Tree Breeding Research Directorate, No: 37, Ankara.

Atay I, Urgenc S, Odabasi T (1970). Eight-year storage test results of seeds of Pinus nigra var. pallasiana, Pinus silvestris and Picea orientalis. J Istanbul Univ Fac For $20 \mathrm{~A}(2): 68-80$.

Barnett JP (1969). Long-term storage of longleaf pine seeds. Tree Planter's Notes 20:22-25.

Barnett JP, Mamonov NI (1989). Biorhythms in conifer seed during extended storage. Ann Sci For 46 (suppl):85s-88s.

Barnett JP, Vozzo JA (1985). Viability and vigor of slash and shortleaf pine seeds after 50 years of storage. For Sci 31:316320.

Bonner FT (2008). Storage of Seeds, p. 85-87. In: Bonner FT, Karrfalt RP (Eds.). The Woody Plant Seed Manual. Agriculture Hand Book 727, USDA Forest Service.

Boydak M, Dirik H, Tilki F, Calikoglu M (2003). Effects of water stress on germination in six provenances of Pinus brutia seeds from different bioclimatic zones in Turkey. Turk J Agric For 27:91-97.

Chin HF (1994). Seedbank: conserving the past for the future. Seed Sci Technol 22:385-400.

Donald DGM, Jacobs CB (1990). The effect of storage time, temperature and container on the viability of the seed of four pine species. S Afr For J 154:41-46.

El-Kassaby YA, Edwards DGW, Taylor DW (1992). Genetic control of germination parameters in Douglas-fir and its importance for domestication. Silvae Genet 41:48-54.

Falleri E (1994). Effect of water stress on germination in six provenances of Pinus pinaster Ait. Seed Sci Technol 22:591599.

Falusi M, Calamassi R, Tocci A (1983). Sensitivity of seed germination and seedling root growth to moisture stress in four provenances of Pinus halepensis Mill. Silvae Genet 32:4-9.

Fraser JW (1971). Cardinal temperatures for germination of six provenances of white spruce seed. Public Forest Service Canada 1290.

Gibson A, Bachealard EP (1987). Provenance variation in germination response to water stress of seeds of some Eucalyptus species. Aus For Res 17:49-58

Gómez-Campo C (1985). Seed banks as an emergency conservation strategy, p. 237-247. In: Gómez-Campo C (Ed.). Plant Conservation in Mediterranean Area. Dr. W. Junk Publishers, Dordrecht.

Gosling P (2007). Raising Trees and Shrubs from Seed. Forestry Commission Practice Guide, Edinburgh.

Gülcü S, Üçler AÖ (2008). Genetic Variation of Anatolian Black Pine (Pinus nigra Arnold. subsp. pallasiana (Lamb.) Holmboe) in the Lakes District of Turkey. Silvae Genet $57(1): 1-5$. 
274

Hawkes JG (1990). Germplasm banks: a method for endangered plant conservation, p. 49-56. In: Hernández-Bermejo JE, Clemente M and Heywood V (Eds.). Conservation Techniques in Botanic Gardens. Koeltz Scientific Books, Königstein.

Hilli A, Tillman-Sutela E, Kauppi A (2003). Germination of pretreated Scots pine seeds after long-term storage. Can J For Res 33(1):47-53.

Kaya Z, Temerit A (1993). The Magnitude and Pattern of Genetic Variation in European Black Pine (Pinus nigra var. pallasiana) Populations in Turkey. Doğa, Turk J Agric For $17: 267-279$

Kaya Z, Temerit A (1994). Genetic Structure of Marginally Located Pinus nigra var. pallasiana Populations in Central Turkey. Silvae Genet 43:272-277.

Koski V, Antola J (1993). National Tree Breeding and Seed Production Programme for Turkey 1994-2003. The Research Directorate of Forest Tree Seeds and Tree Breeding, Ankara, Turkey, p. 52.

Krugman SL, Jenkinson JL (2008). Pinus L., p. 809-847. In: Bonner FT, Karrfalt RP (Eds.). The Woody Plant Seed Manual, Agriculture Hand Book 727, USDA Forest Service.

Mataruga M, Haase DL, Isajev V (2010). Dynamics of seed imbibition and germination of Austrian pine (Pinus nigra Arnold) from extreme habitat conditions within five Balkan provenances. New For 40:229-242.

Moore MB, Kidd FA (1982). Seed sources variation in induced moisture stress germination of ponderosa pine. Tree Planters' Notes 33:12-14.

Pita JM, Sanz V, Escudero A (1998). Seed Cryopreservation of Seven Spanish Native Pine Species. Silvae Genet 47(4):220223.

Quinn JA (1977). Separating genotype from environment in germination ecology studies. Am Midl Nat 97(2):482-489.

Roberts EH (1972). Cytological, genetical and metabolic changes associated with loss of viability, p. 253-306. In: Roberts EH (Ed.). Viability of seeds. Chapman and Hall, London.
SAS Institute Inc. (1990). SAS/STAT user's guide, version 6, 4th ed. [computer manual]. SAS Institute Inc., Cary, N.C.

Simak M, Gustafsson A (1968). Chromosomenaberrationen in alternden Forstsamen. International symposium on biology of woody plants-Arboretum Mlyiiany, CSSR, 1967. The Royal College of Forestry, Stockholm 50, Sweden.

Simola LK (1974). Ultrastructural changes in the seeds of Pinus sylvestris L. during senescence. Stud For Suec Nr. 119, p. 21.

Tilki F (2005). Seed germination and radicle development in six provenances of Pinus sylvestris L. under water stress. Isr J Plant Sci 53(1):29-33.

Tolun AA, Velioğlu E, (Nazlıer) Çengel B, Kaya Z (2000). Genetic structure of black pine (Pinus nigra Arnold subspecies pallasiana) populations sampled from the Bolkar Mountains. Silvae Genet 49:113-119.

Tommasi F, Paciolla C, de Pinto MC, Gara LD (2006). Effects of storage temperature on viability, germination and antioxidant metabolism in Ginkgo biloba L. seeds. Plant Physiol Biochem 44:359-368.

ÜrgençS (1973). Cold storage test for 10 years on Pinusnigra var. Caramanica and Pinus brutia Ten seeds. Proc International Symposium on Seed Processing-Seed Problems, Volume I, Paper No:18, Bergen, Norway. International Union of Forestry Research Organizations.

Wang JH, Baskin CC, Chen W, Du GZ (2010). Variation in seed germination between populations of five sub-alpine woody species from eastern Qinghai-Tibet Plateau following dry storage at low temperatures. Ecol Res 25:195-203.

Weber JC, Sorensen FC (1992). Geographic variation in speed of seed germination in central Oregon ponderosa pine (Pinus ponderosa Dougl. ex Laws.). USDA Forest Service, Pacific Northwest Research Station, Research Paper PNW444, p. 12.

Whittington WJ (1973). Genetic regulation of germination, p. 5-30. In: Heydecker V (Ed.). Seed ecology. Butterworth, London. 